\title{
Implementasi Syariah Compliance pada Akad Murabahah dan Ijarah (Studi Kasus pada KSPPS BMT Fastabiq Jepara)
}

\author{
Silvia Dora Bonita, Aan Zainul Anwar \\ Prodi Ekonomi Islam Universitas Islam Nahdlatul Ulama (UNISNU) Jepara \\ email:aanza@unisnu.ac.id
}

\begin{abstract}
This study aims to determine: 1 ) the principles of financing agreement murabaha and Ijarah in accordance with Islamic law, 2) the implementation of the financing agreement murabaha and Ijarah, and 3) the factors that caused the broken promise in murabaha and ijarah financing agreement in BMT Fastabiq Jepara well as a way to resolve. This research is a field research with a qualitative approach, the research has the characteristics that the data declared in a state appropriately or as their (natural setting), with no change in the shape of symbols or numbers and descriptive based on questions how. And data processing technique is to use a qualitative descriptive technique. The results of the analysis show that: 1) The principles of murabaha financing agreement on BMT Fastabiq Jepara accordance with Islamic sharia as the murabaha financing agreement executed included also wakalah. The principle of Ijarah financing agreement yet on BMT Fastabiq Jepara accordance with Islamic sharia because it is not included wakalah in it. 2) Execution of Murabahah and Ijarah financing agreement in Jepara Fastabiq BMT carried out according to established procedures BMT Fastabiq Jepara. And 3) the factors that led to broken promises in murabaha and Ijarah financing agreement in BMT Fastabiq Jepara is internal and external factors. The steps undertaken BMT Fastabiq Jepara in overcoming these factors include identifying the problem, if there is a problem that complicated it will be a step family, but if they can not be resolved then it will be taken legal action.
\end{abstract}

Keyword : Syariah Compliance, Murabahah

\begin{abstract}
ABSTRAK
Penelitian ini bertujuan untuk mengetahui: 1) prinsip-prinsip akad pembiayaan murabahah dan ijarah, 2) pelaksanaan akad pembiayaan murabahah dan ijarah, dan 3) faktor-faktor yang menyebabkan terjadinya ingkar janji dalam akad pembiayaan murabahah dan ijarah di BMT Fastabiq Jepara serta cara penyelesaiannya. Penelitian ini merupakan jenis penelitian lapangan (field research) dengan pendekatan kualitatif. Dan teknik pengolahan datanya adalah dengan menggunakan teknik deskriptif kualitatif. Hasil dari analisis menunjukkan bahwa: 1) Prinsipprinsip akad pembiayaan murabahah pada BMT Fastabiq Jepara telah sesuai dengan syariah Islam karena dalam akad pembiayaan murabahah yang dilaksanakan disertakan juga akad wakalah. Adapun prinsip akad pembiayaan ijarah pada BMT Fastabiq Jepara belum sesuai dengan syariah Islam karena tidak disertakan akad wakalah di dalamnya. 2) Pelaksanaan akad pembiayaan murabahah dan ijarah pada BMT Fastabiq Jepara dilakukan sesuai prosedur yang telah ditetapkan BMT Fastabiq Jepara. Dan 3) Faktor-faktor yang menyebabkan terjadinya ingkar janji dalam akad pembiayaan murabahah dan ijarah di BMT Fastabiq Jepara adalah faktor intern dan ekstern. Adapun langkah-langkah yang dilakukan BMT Fastabiq Jepara dalam mengatasi faktor-faktor tersebut diantaranya melakukan identifikasi masalah, jika terjadi permasalahan yang rumit maka akan dilakukan langkah kekeluargaan namun bila masih tidak bisa diselesaikan maka akan ditempuh jalur hukum.
\end{abstract}

Kata Kunci: Syariah Compliance, Murabahah, 


\section{PENDAHULUAN}

Kepatuhan terhadap prinsip syariah adalah pemenuhan seluruh prinsip syariah dalam semua kegiatan yang dilakukan sebagai wujud dari karakteristik lembaga itu sendiri, termasuk dalam hal ini koperasi syariah. Melihat dari sudut pandang masyarakat, khususnya pengguna jasa koperasi syariah, kepatuhan syariah merupakan inti dari integritas dan kredibilitas koperasi syariah. Keberadaan koperasi syariah ditujukkan untuk memenuhi kebutuhan masyarakat Islam akan pelaksanaan ajaran Islam secara menyeluruh (kaffah) termasuk dalam kegiatan penyaluran dana melalui bank syariah.

Keyakinan dan kepercayaan masyarakat terhadap koperasi syariah didasarkan dan dipertahankan melalui pelaksanaan prinsip hukum Islam yang diadaptasi dalam aturan operasional institusi tersebut. Jika tanpa adanya kepatuhan terhadap prinsip syariah, maka masyarakat akan kehilangan ke-istimewaan yang mereka cari sehingga akan berpengaruh pada keputusan mereka untuk memilih ataupun terus me-lanjutkan pemanfaatan jasa yang diberi-kan oleh koperasi syariah. Ketidak-patuhan terhadap prinsip syariah akan berdampak negatif terhadap citra koperasi syariah dan berpotensi untuk ditinggalkan oleh nasabah potensial ataupun nasabah yang telah mengguna-kan jasa koperasi syariah sebelumnya.

Produk-produk yang dikeluarkan koperasi syariah cukup variatif, sehingga mampu memberikan pilihan atau alternatif bagi calon nasabah untuk me-manfaatkannya. Dari survei yang pernah dilakukan, kebanyakan koperasi syariah masih mengedepankan produk dengan akad jual beli, diantaranya prinsip murabahah, musyarakah dan ijarah. Hanya saja dalam perjalannya perbankan syariah masih banyak mengalami kendala, kalau dilihat dari aset dan modal sudah sangat lumayan untuk ukuran koperasi syariah yang lahir belakangan, akan tetapi untuk menjangkau nasabah sampai pada sasaran sebagaimana perbankan konvensional banyak meng-alami kendala. Diantara kendala yang menghambat perkembangan koperasi syariah adalah karena masih terbatasnya jaringan koperasi syariah juga masih sedikitnya Badan Usaha Syariah (BUS) dan Bank Pembiayaan Rakyat Syariah (BPRS) serta Unit Usaha Syariah (UUS) dan Lembaga Keuangan Mikro Syariah (LMKS) Baitul Maal wat Tamwil (BMT).

Demi kepuasan masyarakat terhadap pelayanan koperasi syariah, Kementrian Koperasi dan Usaha Kecil Menengah (KUMKM) Republik Indonesia selaku kementrian yang membidangi per-koperasian Indonesia termasuk perkoperasian syariah, mengeluarkan kebijakan tentang pedoman penilaian kesehatan koperasi syariah yang tertuang dalam Peraturan Mentri (Permen) Nomor 35.3/Per/M.KUMKM/X/2007, yang salah satu aspek penilainnya adalah tentang kepatuhan koperasi syariah terhadap prinsip syariah. Dengan adanya peraturan ini, diharapkan setiap koperasi syariah dapat melakukan kegiatan usaha pembiayaan, investasi, dan simpanan berdasarkan jati diri koperasi dan pola syariah secara profesional sesuai dengan prinsip kehati-hatian dan kesehatan, sehingga dapat meningkatkan ke-percayaan dan memberikan manfaat yang sebesar-besarnya kepada anggota dan masyarakat di sekitarnya. Termasuk implementasi pelaksanaan tugas dan tanggung jawab dewan pengawas syariah memiliki hubungan positif dan signifikan terhadap kesehatan finansial (Hasanah, 2015). Namun, koperasi syariah untuk saat ini belum sepenuhnya menjalankan operasionalnya sesuai dengan pedoman penilaian kesehatan koperasi syariah, khususnya dalam hal kepatuhan terhadap Prinsip Syariah.

Kepatuhan terhadap prinsip syariah tidak hanya dari sistem dan aturan saja, namun juga yang terpenting adalah implementasi prinsip syariah yang tidak bisa dipisahkan dari peranan sumberdaya manusia pelaku koperasi syariah. Hal ini ditunjukkan oleh hasil penelitian pada gabungan BMT Mitra di Jepara yang mana 34 karyawan gabungan BMT Mitra dalam pemahaman pelaksanaan prinsip-prinsip Islam kontrak murabahah sebanyak $85 \%$ responden sudah memahami dan melaksanakan sesuai dengan prinsipprinsip Islam, dan 15\% tidak syariah (Anwar \& Edward, 2016). Sedangkan BMT Akbar dan KSUS An-Nur masuk dalam kategori Patuh terhadap prinsip syariah berdasarkan Permen 


\section{K.UMKMnomor 35.3Per/M.KUMKM/X/2007 (Pamungkas, 2016).}

BMT Fastabiq Jepara salah satu prinsipnya adalah untuk mewujudkan koperasi syariah yang dapat menjadi tumpuan masyarakat dalam bidang simpanan dan pembiayaan yang mengutamakan aspek manfaat jangka panjang. Perkembangan pembiayaan di BMT Fastabiq Jepara selama lima tahun terakhir sejak 20122016 dapat dilihat pada tabel berikut:

Tabel. 1

Perkembangan Pembiayaan BMT Fastabiq Jepara

\begin{tabular}{ccc}
\hline Tahun & Jumlah Pembiayaan & Pertumbuhan \\
\hline 2012 & $3,945,447,400$ & $72 \%$ \\
2013 & $6,687,592,000$ & $70 \%$ \\
2014 & $10,129,330,800$ & $51 \%$ \\
2015 & $13,081,964,600$ & $29 \%$ \\
2016 & $12,850,200,980$ & $-2 \%$ \\
\hline
\end{tabular}

Sumber: Laporan RAT (data diolah)

Melihat perkembangan pembiayaan murabahah dan ijarah BMT Fastabiq Jepara seperti terlihat dari tabel di atas menunjukkan peningkatan. Ini memang pantas untuk di kaji dan diteliti mengingat koperasi syariah ini dalam menjalankan kegiatan usahanya sejak berdiri pada tahun 2009 sampai tahun 2016 menunjukkan adanya perkembangan yang cukup meyakinkan dengan telah terbentuknya 6 kantor cabang disamping kantor pusat sebagai induknya. Tujuan dari penelitian ini adalah untuk mengetahui implementasi syariah compliance pada akad Murabahah dan Ijarah pada KSPPS BMT Fastabiq Jepara.

\section{Kepatuhan pada Prinsip Syariah (Syariah Compliance)}

Kepatuhan Syariah adalah syarat mutlak yang harus dipenuhi oleh lembaga keuangan yang menjalankan kegiatan usaha berdasarkan syariah. Arti penting kepatuhan berimplikasi pada keharusan pengawasan terhadap pelaksanaan kepatuhan tersebut. Makna Kepatuhan Syariah (syariah compliance) adalah penerapan prinsipprinsip Islam, syariah dan tradisinya dalam transaksi keuangan dan Perbankan serta bisnis lain yang terkait (Anwar \& Edward, 2016).

Berdasarkan pengertian di atas, dapat dipahami bahwa kepatuhan syariah (syariah compliance) merupakan pemenuhan terhadap nilai-nilai syariah di Lembaga Keuangan Syariah yang menjadikan Fatwa DSN-MUI dan Peraturan Bank Indonesia (BI) sebagai alat ukur pemenuhan prinsip syariah, baik dalam produk, transaksi dan operasional di BMT. Kepatuhan (compliance) memiliki arti mengikuti suatu spesifikasi, standar atau hukum yang telah diatur dengan jelas yang biasanya diterbitkan oleh lembaga atau organisasi yang berwewenang dalam suatu bidang tertentu. Sedangkan, Perbankan Syariah mengartikan Kepatuhan Syariah adalah meningkatkan pengetahuan syariah bagi karyawan sehingga peluang terjadinya pelanggaran syariah berkurang selain itu menciptakan tawaran-tawaran produk dan layanan yang kreaktif dan inovatif, namun tetap patuh pada aturan DSN-MUI. Dewan Pengawas Syariah melengkapi tugas pengawasan yang diberikan komisaris, dimana kepatuhan syariah semakin penting untuk melakukankarena adanya permintaan dari nasabah agar bersifat inovatif dan berorientasi bisnis dalam menawarkan dan produk baru serta untuk memastikan kepatuhan syariah terhadap hukum Islam.

Kedudukan prinsip syariah dalam sistem hukum perbankan syariah nasional adalah sebagai dasar operasional kegiatan lembaga keuangan syariah, khususnya dalam menjalankan fungsi intermediasi. Fungsi intermediasi adalah fungsi yang melekat pada institusi perbankan karena melakukan kegiatan dalam bentuk menerima uang dari investor, menyatukannya, dan menginvestasikan dana yang disatukan tersebut kepada institusi lain (Anwar \& Edward, 2016).

Istilah intermediasi diberikan karena lembaga keuangan dalam kegiatan finansialnya menempatkan diri dalam posisi antara investor dan pengguna akhir investasi. BMT sebagai lembaga inter-mediasi keuangan menjadi fasililator bagi mobilisasi modal yang dititipkan padanya dalam berbagai bentuk, sehingga dari hasil pergerakan tersebut masing-masing pihak, pemilik modal maupun yang memanfaatkannya diuntungkan dengan keberadaan BMT dibanding bila mereka harus menginvestasikan modalnya secara langsung tanpa fasilitator. Fungsi intermediasi yang melekat pada BMT adalah fungsi intermediasi yang terikat pada prinsip syariah. Karakteristik yang dimiliki oleh BMT memberi kewajiban padainstitusi tersebut untuk mematuhi 
dua aturan hukum, yaitu aturan hukum positif nasional khususnya di bidang perbankan serta prinsip.

Kepatuhan syariah merupakan bagian dari pelaksanaan framework manajemen resiko, dan mewujudkan budaya kepatuhan dalam mengelola resiko perbankan Islam. Kepatuhan syariah juga memiliki standar internasional yang disusun dan ditetapkan oleh Islamic Financial Service Board dimana kepatuhan syariah merupakan bagian dari tata kelola lembaga (IFSB, 2009). Kepatuhan syariah merupakan manifestasi pemenuhan seluruh prinsip syariah dalam lembaga yang memiliki wujud karakteristik, integritas dan kredibilitas di BMT. Dimana budaya kepatuhan tersebut adalah nilai, perilaku dan tindakan yang mendukung terciptanya kepatuhan BMT terhadap seluruh ketentuan Bank Indonesia.

\section{Akad Murabahah}

Murabahah adalah akad jual beli barang dengan menyatakan harga perolehan dan memperoleh keuntungan (margin) yang disepakati oleh penjual dan pembeli dan tidak dapat berubah selama berlakunya akad (Naja, 2011).

Murabahah mempunyai dua bentuk yaitu murabahah sederhana dan murabahah kepada pemesan. Murabahah sederhana adalah bentuk akad murabahah ketika penjual memasarkan barangnya kepada pembeli dengan harga sesuai harga perolehan ditambah margin keuntungan yang diinginkan. Murabahah kepada pemesan melibatkan tiga pihak yaitu pemesan, pembeli dan penjual. Bentuk murabahah ini juga melibatkan pembeli sebagai perantara karena keahliannya atau karena kebutuhan pemesan akan pembiayaan (Ascarya, 2008). Model seperti itu disebut murabahah wal wakalah. Sedangkan wakalah adalah akad pemberian kuasa dari seseorang kepada penerima kuasa untuk melaksanakan suatu tugas atas nama pemberi kuasa (Noor, 2007). Bentuk murabahah inilah yang diterapkan perbankan syariah dalam pembiayaan.

\section{Akad Ijarah}

Ijarah adalah perpindahan hak guna atas barang danjasa, melalui pembayaran upah sewa tanpa diikuti dengan pemindahan kepemilikan atas barang itu sendiri (Sudarsono, 2012). Ijarah memiliki kesamaan dengan murabahah karena termasuk dalam katagori natural certainty contracts dan pada dasarnya adalah kontrak jual beli. Perbedaan antara ijarah dan murabahah terletak pada objek transaksi yang diper-jual belikan yaitu dalam pembiayaan murabahah yang menjadi objek transaksi adalah barang, seperti tanah, rumah, mobil dan sebagainya, sedangkan dalam pembiayan ijarah, objek transaksinya adalah jasa, baik manfaat atas barang maupun manfaat atas tenaga kerja, sehingga dengan skim ijarah, bank syari'ah dan lembaga keuangan syari'ah lainnya dapat melayani nasabah yang membutuhkan jasa.

Bentuk pembiayaan ijarah merupakan salah satu teknik pembiayaan ketika kebutuhan pembiayaan investor untuk membeli asset terpenuhi dan investor hanya membayar sewa pemakaian tanpa harus mengeluar-kan modal yang cukup besar untuk membeli aset tersebut. Secara umum timbulnya ijarah disebabkan oleh adanya kebutuhan akan barang atau manfaat barang oleh nasabah yang tidak memiliki kemampuan keuangan. Transaksi ijarah dilandasi adanya perpindahan manfaat (hak guna), bukan perpindahan kepemilikan (hak milik).

Jadi pada dasarnya prinsip ijarah sama saja dengan prinsip jual beli tapi perbedaannya terletak pada objek transaksinya. Bila pada jual beli objek transaksinya barang, sedangkan pada ijarah objek transaksinya adalah barang dan jasa.

\section{METODE PENELITIAN}

Penelitian ini menggunakan jenis penelitian kualitatif yaitu jenis penelitian yang menghasilkan penemuan yang tidak dapat dicapai dengan menggunakan prosedur statistik atau dengan cara kualifikasi lainnya (Moleong, 2009). Objek penelitian adalah BMT Fastabiq Jepara dengan sumber data primer melalui wawancara kepada pengelola (manajer) dan observasi. Sedangkan data sekunder diperoleh dari SOP, aturan-aturan yang berlaku di BMT Fastabiq, serta laporan keuangan BMT Fastabiq Jepara. Pemilihan lokasi ini berdasarkan: Pertama, BMT Fastabiq 
Jepara merupa-kan lembaga keuangan yang menerapkan prinsip syari'ah. Kedua, nasabah BMT Fastabiq Jepara mayoritas beragama Islam.

Teknik pengumpulan data dalam penelitian ini menggunakan teknik wawancara, Observasi Lapangan dan Triangulasi Data. Sesuai dengan metode pendekatan yang diguna-kan, maka dalam penelitian ini analisis yang digunakan adalah analisis deskriptif kualitatif. Analisis kualitatif terdiri dari pokok analisis data yaitu reduksi data (data reduction), penyajian data (data display) dan penarikan kesimpulan (data conclusion).

\section{HASIL DAN PEMBAHASAN}

\section{Prinsip-prinsip akad pembiayaan murabahah pada BMT Fastabiq Jepara}

BMT Fastabiq Jepara adalah salah satu BMT yang menggunakan akad murabahah dalam menjual produk-produk yang ada di BMT-nya. Prinsip-prinsip pelaksanaan akad pembiayaan murabahah di BMT Fastabiq menganut Fatwa DSN 04/DSN-MUI/IV/2000 terntang murabahah.

Bambang Setyo (Manager Operasional) menjelaskan, prinsip-prinsip pokok dalam akad pembiayaan murabahah pada BMT Fastabiq Jepara adalah BMT Fastabiq Jepara melayani pengajuan dengan system jual beli dan menjadi fasilitator atau penjual barang dari supplier kepada anggota. Namun bila pihak BMT Fastabiq tidak dapat memenuhi barang yang mitra butuhkan, melainkan hanya memberikan uang senilai harga barang yang diajukan anggota, maka pihak BMT Fastabiq memberikan akad wakalah didalam perjanjian tersebut.

Para anggota yang mengajukan pembiayaan murabahah di BMT Fastabiq Jepara rata-rata untuk perluasaan usaha, modal kerja, dan pembelian barang seperti sepeda motor, dll. Jadi dalam pembiayaan murabahah di BMT Fastabiq Jepara setelah dana diterima oleh anggota, maka sudah sepenuhnya menjadi hak dari anggota. Apabila dilihat lebih teliti dari realita praktek pembiayaan murabahah di BMT Fastabiq Jepara, dimana pihak BMT dalam pembiayaan murabahah tidak selalu memberikan barang, tetapi hanya memberikan uang seharga barang yang diajukan oleh anggota di awal perjanjian.

Pihak BMT akan menambahkan akad wakalah dalam pembiayaan murabahah baik secara lisan maupun tulisan. Hal ini dilakukan karena pihak BMT memiliki keterbatasan memenuhi barang yang diajukan dengan pembelian barang terlebih dahulu yang diajukan anggota, dan dari pihak BMT berprinsip tidak ingin mempersulit para anggota yang mengajukan pembiayaan murabahah. Pedoman dari pihak BMT yang terpenting antara kedua belah pihak saling rela yaitu penjual/BMT dengan pembeli/anggota.

Adanya tambahan media akad wakalah secara konsisten dalam pem-biayaan murabahah, mengakibatkan pembiayaan murabahah di BMT Fastabiq Jepara sudah sesuai dengan syariah Islam, menjadikan sempurnanya jual beli tersebut dan tidak adanya barang yang diserah terimakan, jadi jika pihak BMT dalam melakukan pembiayaan murabahah hanya memberikan uang seharga barang yang dibutuhkan anggota, dalam pembiayaan tersebut sudah di-selipkan media akad wakalah yang bertujuan untuk mewakilkan dan memberi kuasa kepada anggota untuk mem-beli barang atas nama BMT.

Pada fatwa Dewan Syari'ah Nasional NO: 04/DSN-MUI/ IV/2000 tentang murabahah dijelaskan jika lembaga keuangan hendak mewakilkan kepada nasabah untuk membeli barang dari pihak ketiga, akad jual beli murabahah harus dilakukan setelah barang, secara prinsip menjadi milik lembaga keuangan. Jadi jika pihak BMT ingin mewakilkan pembelian barang dari pihak ketiga (supplier) kepada anggota, maka kedua pihak harus menanda tangani kesepakatan agensi, dimana pihak BMT memberikan otoritas kepada anggota untuk menjadi agennya untuk membeli barang dari pihak ketiga atas nama BMT, dengan kata lain, anggota telah menjadi wakil dari BMT untuk membelikan barang. Kemudian anggota membeli barang tersebut atas nama BMT, dan kepemilikannya hanya sebatas sebagai agen dari pihak BMT. Sehingga pemberian kuasa (wakalah) dari pihak BMT kepada anggota atau pihak ketiga, harus dilakukan sebelum akad jual beli murabahah terjadi.

Kemudian pada Peraturan Bank Indonesia (PBI) NO. 7/46/ PBI/2005 tanggal 
14 Nopember 2005 tentang standarisasi akad, Bank Indonesia menegaskan kembali penggunaan media wakalah dalam murabahah pada pasal 9 ayat 1 butir D yaitu dalam hal lembaga keuangan mewakilkan kepada nasabah (wakalah) untuk membeli barang, maka akad murabahah harus dilakukan setelah barang secara prinsip menjadi milik lembaga keuangan.

Dari gambaran praktek pembiayaan murabahah di BMT Fastabiq Jepara, terlihat sudah sesuai dengan ketentuan syariah Islam, karena sudah diber-lakukannya akad wakalah dalam perjanjian pembiayaan murabahah. Jadi pada saat akad murabahah dilakukan dengan anggota, pihak BMT tidak mem-berikan barang, hanya memberikan uang seharga barang yang diajukan, sehingga secara prinsip barang belum menjadi milik BMT, karena ketika pihak BMT hanya memberikan sejumlah uang seharga barang yang diajukan anggota, pihak BMT menyelipkan media wakalah. Hal ini jelas sudah sesuai aturan syariah Islam.

Praktek pembiayaan murabahah di BMT Fastabiq Jepara pada isi surat perjanjian. Jika dilihat dari isi surat perjanjian murabahah di BMT Fastabiq Jepara, di surat perjanjian tersebut tertulis bahwa pihak BMT mewakilkan dan memberi kuasa (wakalah) kepada anggota untuk membeli barang tersebut secara mandiri. BMT dalam melakukan pembiayaan murabahah memberikannya uang seharga barang tersebut, serta diselipkan media wakalah baik itu lisan maupun tertulis. Agar ketika salah satu dari mereka (BMT atau anggota) ada yang lupa dengan transaksi itu, masih ada bukti catatannya. Jadi pada surat perjanjian dicantumkan redaksi akad wakalah, bahwa pihak BMT memberi kuasa kepada anggota untuk membeli komoditas secara mandiri. Dengan demikian, pada surat perjanjian akad murabahah di BMT Fastabiq Jepara ditambahkan redaksi bahwa BMT memberi kuasa kepada anggota sebagai wakil dari pihak BMT untuk membeli komoditas secara mandiri.

Berdasarkan observasi lapangan, penambahan media wakalah baik itu lisan maupun tertulis tidak akan merugikan dan merepotkan pihak siapapun, baik itu pihak BMT maupun anggota. Karena jika dilihat untuk penambahan media wakalah secara lisan, yang dilakukan pihak BMT yaitu melakukan pemberian kuasa/ wakalah ke seluruh anggota sebelum melakukan akad murabahah. Kemudian untuk pemberian kuasa secara tertulis, pihak BMT dalam perjanjian murabahah sudah menambahkan redaksi pemberian kuasa ke anggota untuk membeli barang secara mandiri. Kemudian dalam hal ini, penulis tidak melihat adanya anggota yang dipersulit, semua kebijakan pada pembiayaan murabahah yang berwenang adalah pihak BMT sebagai penjual, jadi menurut penulis pembeli/ anggota akan mamatuhi aturan yang berlaku.

\section{Prinsip-prinsip akad pembiayaan ijarah pada BMT Fastabiq Jepara}

Pembiayaan ijarah pada BMT Fastabiq Jepara merupakan pembiayaan dengan akad sewa yang objeknya berupa manfaat dari suatu barang atau jasa. Akad ijarah yang ada di BMT Fastabiq Jepara bukan berupa menyewakan suatu barang atau jasa melainkan sebagai pihak pendanaan untuk anggota yang kemudian digunakan anggota untuk menyewa suatu barang atau jasa dengan cara pembayaran bisa melalui cicilan. Atas transaksi peng-gunaan dana tersebut dikenakan mem-bayar fee sebesar 2\% (dua persen). Dalam ijarah ini besarnya ujrah atau fee ditentukan bukan berdasarkan nominal tetapi berdasarkan jangka waktu dan prosentase atas besarnya pinjaman/ plafond.

BMT Fastabiq Jepara mempunyai macammacam produk pembiayaan, salah satu produk yang ditawarkan oleh BMT kepada calon anggota yaitu ijarah dimana BMT memberikan pinjaman berupa uang kepada calon anggota untuk menyewa barang atau jasa, atas transaksi penggunaan dana pinjaman tersebut oleh calon anggota, berapapun nominalnya margin keuntungannya sebesar 2\%. Dalam ijarah ini besarnya ujrah ditentukan bukan berdasarkan nominal pinjaman tetapi berdasarkan jangka waktu dan prosentase atas besarnya pinjaman, serta tidak sesuai dengan fatwa DSN No. 44/ DSN-MUI/ VII/2004 dan No. 09/DSN-MUI/ VI/2000 tentang ijarah, hal ini dikarenakan pihak BMT Fastabiq Jepara tidak bekerja sama dengan pihak ketiga sebagai tempat penyedia jasa. Maka pihak BMT Fastabiq Jepara tidak melakukan pekerjaan tertentu sehingga tidak berhak mendapat-kan ujrah, 
ujrah yang dibebankan kepada anggota selama ini lebih menyerupai tambahan, jadi menurut peneliti lebih baiknya menggunakan akad qard dan tidak membebankan tambahan kepada nasabah pada kesepakatan diawal.

\section{Pelaksanaan akad pembiayaan murabahah pada BMT Fastabiq Jepara}

Bambang Setyo (Manager Operasional BMT Fastabiq Jepara) menjelaskan BMT Fastabiq Jepara memiliki keterbatasan maka sebagian dapat menghadirkan barang, sebagian berkerja sama dengan supplier dan ada yang kami wakalah-kan. Jika BMT Fastabiq tidak dapat menghadirkan barang dalam akad tersebut, melainkan hanya uang senilai harga barang tersebut kepada anggota maka kami akan me-wakalahkan kepada anggota didalam perjanjian tersebut untuk membeli barang yang diajukannya.

Alasan diberikannya akad wakalah didalam perjanjian murabahah baik secara tertulis maupun lisan adalah untuk mempermudah pihak BMT dan tidak mempersulit calon anggota yang meng-ajukan pembiayaan. Kebanyakan anggota BMT Fastabiq Jepara adalah orang awam yang tidak begitu paham tentang hukumhukum tersebut. Beliau juga berpendapat bahwa apabila didaerah ini diterapkan seratus persen sistem lembaga keuangan syariah yang murni maka belum tepat untuk waktu sekarang, hal ini disebabkan karena para calon anggota tidak mau dipersulit dalam mengajukan pembiayaan dan menginginkan hal yang instan, cepat dan mudah. Namun kami berusaha dengan semaksimal mungkin untuk menerapkan pembiayaan murabahah yang sesuai dengan syariah Islam.

Prosedur pelaksanaan akad murabahah sesuai Standart Oprasioanl Prosedur (SOP) Pembiayaan BMT Fastabiq adalah pertama, Calon anggota murabahah mengisi permohonan pembiayaan. Kedua, Calon anggota mengumpulkan persyaratan yang telah ditetapkan oleh BMT yaitu identitas diri/ KTP/SIM, rekening listrik dan fotocopy kartu keluarga, Menyerahkan fotocopy BPKB/ sertifikat tanah sebagai jaminan. Surat persetujuan dari istri jika suami yang mengajukan pembiayaan dan juga sebaliknya jika suami yang mengajukan pembiayaan harus mendapat persetujuan istri. Ketiga Siap menerima silaturrahmi dari karyawan BMT Fastabiq Jepara.

Kemudian di proses dan di survey oleh karyawan BMT, hasil dari survey dilaporkan ke manager untuk mendapat persetujuan, apabila manager menyetujui kemudian hari berikutnya pihak BMT menghubungi calon anggota untuk datang ke kantor.

Langkah pertama Akad murabahah dilakukan, calon anggota mendatangani perjanjian akad murabahah, petugas meminta agunan yang asli, petugas memberikan surat serah terima agunan kepada calon mitra, dan kedua Teller mencairkan sesuai dengan persetujuan bagian pem-biayaan sejumlah uang senilai harga asset yang diajukan anggota. Murabahah yang dilakukan di BMT Fastabiq Jepara merupakan jual beli dengan sistem bayar tunai di angsur atau tunai di akhir. Praktek pembiayaan murabahah di BMT Fastabiq Jepara dilaksanakan berdasarkan prosedur dengan beberapa syarat yang diajukan oleh pihak BMT Fastabiq Jepara kepada para anggotanya. Pertama-tama anggota yang melakukan pembiayaan murabahah mengajukan permohonan kepada BMT kemudian anggota tersebut menyerahkan syarat-syarat yang telah ditentukan oleh pihak BMT.

Setelah permohonan tersebut di-proses kemudian pihak BMT melakukan survey kepada calon anggota tersebut. Apabila manager menyetujui per-mohonan dan hasil survey calon anggota tersebut telah disetujui, kemudian menanda-tangani surat perjanjian akad murabahah. Sebelum menanda tangani perjanjian tersebut, akan ditentukan terlebih dahulu jangka waktu, harga pokok dan keuntungan yang diinginkan oleh pihak BMT. Selanjutnya anggota tersebut diberikan barang yang telah diajukan atau sejumlah uang seharga aset yang diajukan oleh anggota tersebut. Dalam pelaksanaan akad tersebut pihak BMT terkadang menghadirkan barang dan yang sering diaplikasikan pihak BMT memberikan sejumlah uang kepada anggotanya sebesar harga barang yang ingin dibeli.

Akad murabahah yang dilaksanakan di BMT Fastabiq Jepara ini apabila dilihat lebih detail belum sesuai dengan syari'ah. 
Ketidaksesuaian itu terjadi pada pengadaan barang yang tidak selalu terpenuhi dan pihak BMT hanya mengeluarkan uang seharga aset yang diajukan oleh anggota. Namun dikarena-kan pihak BMT mengeluarkan uang seharga asset tersebut dan menambahkan akad wakalah dalam pembiayaan murabahah, untuk mewakilkan kepada anggota membeli barang tersebut secara mandiri maka pelaksanaan akad murabahah di BMT Fastabiq Jepara sudah sesuai dengan syariah. Pihak BMT Fastabiq Jepara memberikan akad wakalah atau kuasa kepada anggotanya baik anggota tersebut meminta ditambah-kan akad wakalah ataupun tidak. Jika dilihat dari isi surat perjanjian murabahah di BMT Fastabiq Jepara, terdapat redaksi tertulis bahwa pihak BMT memandatkan atau memberi kuasa ke anggota untuk membeli sendiri barang yang dibutuhkannya. Dari pemaparan di atas, peneliti dapat menarik kesimpulan bahwa transaksi pembiayaan murabahah yang dilaksanakan di BMT Fastabiq Jepara sudah sesuai dengan prinsip murabahah.

Adapun peranan Dewan Pengawas Syariah (DPS) di BMT Fastabiq Jepara adalah melakukan pengecekan terhadap akad dan memberikan pelatihan kepada karyawan terutama jika DPS memperoleh pelatihan atau informasi yang baru.

\section{Pelaksanaan akad pembiayaan ijarah pada BMT Fastabiq Jepara}

Pelaksanaan akad pembiayaan ijarah pada BMT Fastabiq Jepara memakai system pendanaan kepada anggota untuk menyewa suatu barang atau jasa contohnya perlengkapan resepsi pernikahan, atas transaksi peggunaan dana tersebut dikenakan membayar fee sebesar $2 \%$ (dua \%), dan besarnya ujrah ditentukan berdasarkan jangka waktu dan prosentase atas besarnya pinjaman/ plafond.

Dalam pengajuan pembiayaan ijarah pada BMT Fastabiq Jepara mempunyai ketentuan umum sebagai yaitu mengajukan permohonan pem-biayaan, pembiayaan dipergunakan untuk sewa barang atau jasa, menyerahkan fotocopy KTP dan KSK atau identitas lainnya, Fotocopy tagihan listrik atau kredit lainnya, Fotocopy jaminan atau agunan (BPKB atau sertifikat), dan Mengisi formulir pengajuan.
Di dalam pembiayaan yang ada di BMT Fastabiq Jepara yang dipakai adalah akad ijarah, sebagaimana yang kita ketahui akad ijarah adalah akad pemindahan hak guna (manfaat), dan di BMT Fastabiq Jepara ini yang di-pinjamkan berupa uang, seharusnya berupa barang dan jasa sehingga penyewa bisa menikmati barang yang disewakan untuk diambil manfaatnya. Kalau kita lihat praktek ijarah yang ada di BMT Fastabiq Jepara ini memakai sistem meminjamkan uang bukan meminjamkan barang, kalau meminjamkan barang dalam ijarah itu harus ada jasa yang dimanfaatkan. Namun yang terjadi mitra diberi uang untuk menyewa suatu jasa tetapi tidak disertakan akad wakalah untuk mitra menyewa kepada pihak ke tiga.

Pembiayaan ijarah yang ada di BMT Fastabiq Jepara seharusnya akad yang digunakan bukan akad ijarah melainkan akad qardh. Sebab ijarah dalam pengertiannya adalah upah-mengupah, jika BMT melakukan kerjasama dengan pihak ketiga sebagai penyedia jasa seperti untuk menyewa suatu barang, sehingga pihak BMT Fastabiq Jepara bisa men-dapatkan ujrah. Qardh adalah pinjaman yang diberikan kepada anggota yang membutuhkan. Anggota wajib mengembalikan jumlah uang yang diterima pada waktu yang telah disepakati oleh kedua belah pihak. Peminjam dapat memberikan tambahan dengan suka rela kepada koperasi selama tidak diperjanjikan dalam akad. Dalam dunia perbankan Syariah, jika nasabah tidak dapat mengembalikan bagian atau seluruh kewajibannya pada saat yang telah disepakati dan telah memastikan ketidak-mampuannya, maka dapat diperpanjang waktu pengambilan, atau menghapus sebagian atau seluruh kewajibannya.

Jadi, akad ijarah yang digunakan untuk meminjamkan uang yang ada di BMT Fastabiq Jepara ini tidak tepat dan tidak sesuai dengan syariah Islam, dan Fatwa DSN No. 44/DSN-MUI/VII/ 2004 tentang ijarah hal ini dikarenakan pihak BMT Fastabiq Jepara tidak bekerja sama dengan pihak ketiga sebagai tempat penyedia jasa. Maka pihak BMT Fastabiq Jepara tidak melakukan pekerjaan tertentu sehingga tidak berhak mendapatkan ujrah, ujrah yang di-bebankan 
oleh nasabah selama ini lebih menyerupai tambahan, jadi me-nurut peneliti lebih baiknya meng-gunakan akad qardh dan tidak membebankan tambahan kepada nasabah pada kesepakatan diawal.

Faktor-faktor penyebab terjadinya kemacetan pembayaran dalam akad pembiayaan murabahah dan ijarah di BMT Fastabiq Jepara serta cara penyelesaiannya

Bambang Setyo menjelaskan penyebab terjadinya kemacetan pem-bayaran atau pembiayaan bermasalah dalam akad pembiayaan murabahah dan ijarah di BMT Fastabiq Jepara disebab-kan oleh dua faktor yaitu pertama faktor internal, yaitu faktor yang terjadi di dalam BMT itu sendiri. Pihak BMT melakukan beberapa kesalahan diantaranya adanya keteledoran atau kurang teliti dalam menganalisis per-mohonan pembiayaan kepada mitra/ anggota, kurang adanya pengawasan atau survey lebih lanjut dari pihak BMT mengenai jalannya usaha setelah dicairkannya pembiayaan, adanya kolusi dari pihak analis pembiayaan dengan debitur.

Kedua faktor eksternal, yaitu faktor yang terjadi diluar kekuasaan manajerial BMT. Ada beberapa penyebab diantaranya yaitu kurangnya kejujuran atau sikap tidak amanah dari pihak anggota dalam pengisian berkas pengajuan pembiayaan, adanya unsur kesengajaan, adanya unsur ketidak sengajaan, adanya desakan kebutuhan yang meyebabkan nasabah menggunakan dana tersebut, dan Bencana alam.

Lebih lanjut Bambang Setyo menjelaskan BMT Fastabiq Jepara dalam menangani kredit macet tidak langsung menarik ataupun menjual jaminan yang telah dijaminkan oleh nasabah. Apabila terjadi hal demikian, pihak BMT akan melakukan penelitian lebih lanjut bagaimana hal ini bisa terjadi dengan menggunakan pendekatan secara kekeluargaan (ukhuwah).

Langkah yang ditempuh BMT Fastabiq Jepara dalam proses penanganan pembiayaan murabahah dan ijarah bermasalah sesuai dengan Standart Oprasional Prosedur Pembiayaan BMT Fastabiq Jepara pertama apabila terjadi kredit macet, maka pihak BMT melakukan identifikasi mengenai faktor penyebab permasalahannya. Kedua jika terjadi permasalahan yang rumit, maka nasabah diberi waktu untuk melunasi kewajibannya. Ketiga officer mendatangi nasabah untuk mengetahui keadaan nasabah yang sebenarnya. Keempat memberikan surat peringatan (SP) sebanyak 3 kali. Kelima apabila dengan surat peringatan belum bisa menyelesaikan masalah, maka pihak BMT memberi kesempatan kepada nasabah agar bisa melunasi sisa pokoknya saja. Jika melunasi sisa pokoknya masih tidak mampu, maka pihak BMT bermusyawarah lagi dengan nasabah bagaimana jika barang jaminan dijual untuk menutupi sisa kekurangan pembayaran, apabila uang penjualan barang tersebut masih tersisa, maka akan dikembalikan lagi kepada nasabah.

Salah satu masalah yang sering dihadapi di BMT Fastabiq Jepara adalah pembiayaan murabahah dan ijarah bermasalah. Pembiayaan murabahah dan ijarah bermasalah diartikan sebagai suatu keadaan dimana nasabah tidak sanggup mem-bayar sebagian atau seluruhnya kepada pihak BMT yang telah disepakati dalam perjanjian pem-biayaan. BMT Fastabiq Jepara meng-artikan pembiayaan bermasalah atau kredit macet sebagai keadaan dimana nasabah mengalami keterlambatan dalam mengangsur pembiayaan yang jangka waktunya lebih dari 3 bulan. Berikut adalah tabel kemacetan dalam pembayaran pada tahun 2016,

Tabel. 2

Pembiayaan Macet di BMT Fastabiq Jepara Tahun 2016

\begin{tabular}{ll}
\hline \multicolumn{1}{c}{ Kategori } & \multicolumn{1}{c}{ Jumlah } \\
\hline Macet & Rp. 149.265.422,- \\
Diragukan & Rp. 205765.500,- \\
Tidak lancar & Rp. 286.568.500,- \\
\hline
\end{tabular}

Sumber: Laporan Keuangan BMT Fastabiq 2016

Berdasarkan tabel di atas dapat diketahui bahwa pembiayaan ber-masalah yang ada di BMT Fastabiq Jepara dapat dikategorikan menjadi tiga kategori yaitu kategori pembayaran macet sebesar Rp. 149.265.422,kategori pembayaran diragukan sebesar Rp. 205.765.500,- dan kategori tidak lancar sebesar Rp. 286.568.500,- 


\section{KESIMPULAN}

Berdasarkan pembahasan dalam penelitian di lembaga keuangan syariah BMT Fastabiq Jepara ini maka dapatlah disimpulkan:

Prinsip-prinsip akad pembiayaan murabahah pada BMT Fastabiq Jepara telah sesuai dengan syariah Islam meskipun belum sepenuhnya, karena dalam akad pembiayaan murabahah yang dilaksanakan di-sertakan juga akad wakalah dimana pihak BMT Fastabiq Jepara hanya memberikan uang kemudian mem-berikan hak kuasa kepada nasabah untuk membelanjakan uang tersebut secara mandiri. Adapun prinsip-prinsip akad pembiayaan ijarah pada BMT Fastabiq Jepara belum sesuai dengan syariah Islam karena tidak bekerja sama dengan pihak ketiga dan tidak disertakan akad wakalah di dalamnya.

Pelaksanaan akad pembiayaan murabahah dan ijarah pada BMT Fastabiq Jepara yaitu nasabah mengajukan permohonan kepada pihak BMT Fastabiq Jepara kemudian anggota menyerahkan syarat-syarat yang telah ditentukan oleh pihak BMT yang selanjutnya pihak BMT akan melakukan survey terhadap nasabah dan setelah permohonan disetujui kemudian nasabah menanda tangani surat perjanjian akad murabahah dan ijarah. Sebelum menanda tangani perjanjian tersebut, akan ditentukan terlebih dahulu jangka waktu, harga pokok dan keuntungan yang diinginkan oleh pihak BMT untuk akad murabahah dan ditentukan terlebih dahulu jangka waktu beserta ujroh untuk akad ijarah. Selanjutnya anggota tersebut diberikan sejumlah uang seharga aset yang diajukan oleh anggota tersebut dengan di-sertakan akad wakalah didalamnya untuk akad pembiayaan murabahah. Pembiayaan bermasalah yang ada di BMT Fastabiq Jepara dapat di-kategorikan menjadi tiga kategori yaitu kategori pembayaran macet sebesar Rp.149.265.422 atau 1.16\%,kategori pembayaran diragukan sebesar Rp.205.765.500,- atau 1.6\% dan kategori tidak lancar sebesar Rp. 286.568.500,- atau 2.23\% dari jumlah pembiayaan sebesar Rp. 12.850.200.980,-

\section{DAFTAR PUSTAKA}

Anwar, A. Z., \& Edward, M. Y. (2016). Analisis Syariah Compliance Pembiayaan Murabahah pada Gabungan Koperasi BMT Mitra Se-Kabupaten Jepara. . The 3rd University Research Colloquium. Kudus: STIKES Muahammadiyah.

Ascarya. (2008). Akad dan Produk Bank Syari'ah. Jakarta: Raja Grafindo Persada.

Hasanah, U. (2015). Kepatuhan Prinsip-Prinsip Syariah dan Islamic Corporate Governance terhadap Kesehatan Finansial pada Bank Umum Syariah. Semarang: Fakultas Ekonomi Universitas Negeri Semarang.

IFSB. (2009). Guiding Principles on Shariah Governance Systems for Institutions Offering Islamic Financial Services. Islamic Financial Service Board (IFSB).

Moleong, L. J. (2009). Metodologi Penelitian Kualitatif. Bandung: Remaja Rosda Karya.

Naja, H. D. (2011). Akad Bank Syariah. Yogyakarta: Pustaka Yustisia.

Noor, M. D. (2007). Ekonomi Syariah versi Salah. Pasuruan: Pustaka Sidogiri.

Noor, M. D. (207). Ekonomi Syariah Versi Salaf. Pasuruan: Pustaka Sidogiri.

Pamungkas, B. (2016). Analisis Kepatuhan Koperasi Syariah Terhadap Prinsip Syariah Berdasarkan Permen K.UMKM Nomor: 35.3/ Per/M.KUMKM/ X/2007 (Studi Kasus di BMT Akbar dan KSUS an-Nur Kecamatan Tawangsari Tahun 2015). Surakarta: Fakultas Agama Islam Universitas Muhammadiyah . Sudarsono, H. (2012). Bank dan Lembaga Keuangan Syariah. Yogyakarta: Ekonisia. 